\title{
QILIN: TOLERANSI KEBERAGAMAN SEBAGAI IDE PENCIPTAAN KARYA KERAMIK SENI
}

\author{
Abibawa Wicaksana \\ Pascasarjana \\ Institut Seni Indonesia Yogyakarta, Indonesia \\ e-mail : knevicce@gmail.com \\ Diterima : 19 Juli 2020. Disetujui : $2 \underline{5}$ November 2020. Dipublikasikan : 1 Desember 2020 \\ (c) () $\begin{aligned} & \text { C2020- DESKOVI Universitas Maarif Hasyim Latif. Ini adalah artikel dengan akses } \\ & \text { terbuka di bawah lisensi CC BY } 4.0 \text { (https://creativecommons.org/licenses/by/4.0/) }\end{aligned}$
}

\begin{abstract}
ABSTRAK
Indonesia merupakan negara dengan masyarakat yang majemuk yang memiliki berbagai ras, agama, suku, kebudayaan, dan lain sebagainya. Meskipun demikian, hingga hari ini kabar mengenai perilaku intoleran masih sering ditemui. Kejadian-kejadian intoleran tersebut pada umumnya dialami oleh mereka yang memiliki ras, suku, keyakinan, kebudayaan, pola berpikir, pilihan politik, ataupun kondisi fisik yang berbeda. Sebagai respons terhadap permasalahan tersebut, muncul keinginan untuk menciptakan karya yang berkaitan dengan Bapak Pluralisme Indonesia atau Gus Dur. Dikarenakan salah satu hasil perjuangannya melawan intoleransi adalah pengembalian hak etnis Tionghoa, maka karya yang kemudian tercipta adalah karya-karya dengan objek yang berasal dari kebudayaan Tionghoa. Sebagai hasil, tercipta dua karya keramik terakota dengan qilin sebagai objeknya. Pemilihan qilin tersebut tidak hanya dikarenakan ia merupakan makhluk mitologi dari kebudayaan Tionghoa, tetapi juga dikarenakan kaitannya dengan kisah kelahiran Konfusius, nabi agama Konghucu. Supaya konsep toleransi dengan mengangkat penghapusan intoleransi yang dialami etnis Tionghoa di Indonesia tidak hilang, qilin pada karya ini juga dibuat dalam kondisi tidur. Kondisi tersebut dibuat sebagai tanda bahwa si hewan mitologi ini sedang tenang, terbebas dari ancaman larangan yang pernah dialami oleh etnis Tionghoa di Indonesia dari tahun 1967 hingga tahun 2000.
\end{abstract}

Kata kunci: penciptaan seni, keramik, qilin, toleransi

\begin{abstract}
Indonesia is a country that has a large variety of races, religions, ethnicities, cultures, etc., within its people. Even though it is a pluralistic country, having something like a different race, ethnicity, belief, culture, mindset, political choice, or even physical conditions can still be an issue. As a response to this problem, I then created two artworks as a reminder about the legacy of Indonesia's third president who is known for his fight against discrimination, Abdurrahman Wahid. Since one of his most known legacies is the removal of the Chinese ban in Indonesia at year 2000, the model used in the creation of the artworks is from a myth in Chinese traditions. As a result, two qilin terracotta ceramic artworks were created. The qilin was used not only because it's a Chinese mythological creature, but also because of its relation to the legend of the birth of the Chinese philosopher who's also known as the prophet of the Confucianism, Confucius. To express the freedom due to the ban removal, the qilins in these artworks were then made sleeping. This position was used to make these mythological creatures look relaxed, or in other words, look like it's free from the predator that preys on it from year 1967 to year 2000.
\end{abstract}

Keyword: artwork, ceramic, qilin, tolerance

\section{PENDAHULUAN}

Perbedaan merupakan sesuatu yang tidak bisa dihindari. Meskipun sama-sama berupa makhluk hidup, di antara satu makhluk dengan lainnya tidak ada yang sama. Tidak hanya variasi jenis makhluk yang beragam, di antara jenis makhluk yang sama pun tidak ada yang memiliki kesamaan yang mencapai $100 \%$, baik bentuk fisik maupun wataknya. Oleh karenanya, dengan sewajarnya pula apabila manusia tidak ada yang sama, apalagi di Indonesia yang merupakan negara dengan banyak sekali ras, suku bangsa, kebudayaan, bahasa daerah, keyakinan, dan lain-lain. Keberagaman di Indonesia tersebut tercermin pada semboyan 'Bhineka Tunggal Ika' (Setiawan, 2017:61) dan dilindungi oleh Pancasila, UUD 1945 dan UU No. 39 tahun 1999 (Wicaksono, 2018:174-175), 
Meski Indonesia memiliki keragaman pada manusianya namun sangat disayangkan bahwa hingga hari ini intoleransi terhadap perbedaan masih ada, apalagi intoleransi merupakan ancaman yang dapat memecah-belah bangsa (Sari \& Samsuri, 2020). Akhirakhir ini pun, kejadian-kejadian intoleran makin bertambah, seiring dengan pihak mayoritas yang sering menyuarakan tuntutan-tuntutan, bahkan hingga unjuk rasa yang berjilid-jilid. Pihak-pihak minoritas pun ikut melawan dengan mengekspresikan identitas mereka. Hal tersebut menjadikan isu-isu yang berbau SARA (Suku, Agama, Ras, dan Antargolongan) menjadi sesuatu yang sangatlah sensitif (Sari, 2017:140).

Di antara kasus-kasus intoleransi di Indonesia, salah satu jenis yang paling terlihat adalah kejadiankejadian yang berkaitan dengan perbedaan pola pikir, seperti perbedaan kebudayaan, termasuk di antaranya beda keyakinan. Salah satu contohnya adalah kasus penolakan terhadap warga dengan agama yang berbeda di Bantul beberapa waktu yang lalu (Pertana, 2019). Selain masalah keyakinan, terdapat pula kejadiankejadian yang terjadi akibat perbedaan pandangan atau cara berpikir. Contoh yang sangat terlihat terjadi pada adanya penggunaan istilah "cebong" dan "kampret" pemilihan umum (pemilu) 2019 di Indonesia (Kusuma, 2019:276).

Selain masalah intoleransi yang terjadi akibat pilihan, banyak pula yang terjadi akibat hal-hal yang di luar kekuasaan korbannya. Salah satunya contohnya terjadi akibat kondisi fisik yang tidak biasa seperti yang pernah terjadi pada kasus dokter gigi Romi setelah mengikuti ujian CPNS akibat kelumpuhan yang dialaminya (CNN Indonesia, 2019).

Sebagai manusia yang tidak sempurna, penulis juga pernah mengalami hal serupa. Dikarenakan pernah cidera di kepala, diperparah dengan beberapa penyakit yang dialami setelahnya, penulis mengalami stroke ringan yang menghalanginya berkegiatan fisik, dan mengalami kondisi yang mengakibatkannya sering mengalami sakit kepala. Kondisi yang tidak umum terjadi tersebut tidak jarang berujung dengan anggapan bahwa penulis berpura-pura sakit. Hal tersebut berakibat pada banyak tinadakan kurang menyenangkan yang dialami penulis, seperti nilai pelajaran dan perijinan di sekolah yang dipersulit, ucapan-ucapan yang tidak menyenangkan dari orangorang sekitar seperti sindiran (contohnya seperti membanding-bandingkan dengan orang lain yang tidak mengalami kondisi serupa), dan lain sebagainya.

Selain masalah kondisi fisik, terdapat pula intoleransi karena masalah ras atau suku. Salah satunya adalah diskriminasi terhadap etnis Tionghoa. Meskipun keberadaannya memperkaya kebudayaan di Indonesia, (Purbasari \& Suharno, 2019), pada tahun 1967 hak-hak etnis Tionghoa untuk mengekspresikan ke-Tionghoaannya dicabut yang mengakibatkan mereka tidak boleh menganut agama dari tempat mereka berasal (Fittrya, 2013:160). Selain itu mereka juga dilarang untuk menggunakan nama berbahasa Tionghoa (dipaksa mengganti nama), dan mendapat pembatasan dalam hal pendidikan dan lapangan pekerjaan (Huda, 2010:166). Beruntung bagi mereka, Indonesia kemudian mendapatkan sosok presiden ketiga yang pluralis yang kemudian pada tahun 2000 mengeluarkan Keppres No.6/2000 yang mencabut semua larangan tersebut (Eriyanti, 2006:32).

Presiden ketiga Indonesia, Abdurrahman Wahid alias Gus Dur, selain dikenal sebagai seorang politisi yang pernah menjadi kepala negara di Indonesia, ia juga dikenal sebagai seorang tokoh agama dan seorang budayawan. Ia juga merupakan seseorang yang sangat menjunjung tinggi keberagaman dan sangat menentang kekerasan, sehingga ia juga diberi julukan 'Bapak Pluralisme' (Setiawan, 2017:58-59).

Untuk mengenang perjuangan Gus Dur, muncul keinginan untuk menciptakan karya yang merepresentasikan salah satu hasil dari perjuangannya menghilangkan intoleransi, yaitu pencabutan Inpres No.14/1967 yang melarang ditampilkannya kebudayaan Tionghoa di depan umum. Oleh karenanya penciptaan karya ini akan menciptakan karya yang merepresentasikan kebudayaan Tionghoa. Terdapat banyak hal di dalam kebudayaan Tionghoa yang bisa digunakan di dalam penciptaan ini, salah satunya seperti yang sering terlihat di pecinan, klenteng, dan hal-hal yang berkaitan dengan kebudayaan etnis Tionghoa, yaitu naga (liong/long/lung). Meskipun long merupakan makhluk yang sangat identik dengan negeri Tiongkok, namun penulis menemukan sosok lain yang dianggap lebih sesuai untuk penciptaan ini.

Selain naga, terdapat pula makhluk lain yang memiliki ciri khas serupa dengan long yang juga pasti terlihat di klenteng, yaitu makhluk yang terkadang disebut dragon-horse, yaitu qilin. Dibandingkan long, makhluk ini lebih sesuai untuk digunakan sebagai objek penciptaan dikarenakan selain merupakan makhluk yang identik dengan kebudayaan Tionghoa, makhluk ini juga memiliki legenda yang berkaitan dengan tokoh penting agama Konghucu, yaitu Konfucius (Coleman, 2007:211). Hal tersebut menjadikan sosok qilin sebagai sosok yang dipilih sebagai objek penciptaan karya ini. Objek yang terpilih ini, akan menggunakan keramik sebagai media penciptaannya.

\section{METODE PENCIPTAAN}

Penelitian di dalam menciptakan karya ini mengacu metode "3 tahap 6 langkah" milik Gustami, namun dengan sedikit sedikit penambahan. Secara umum, awal dari metode ini adalah eksplorasi yang bertujuan mencari ide, konsep, dan landasan teori dari karya yang akan diciptakan. Tahap selanjutnya adalah perancangan yang bertujuan membuat rancangan sekaligus membuat prototipe dari rancangan tersebut. Kemudian, tahap terakhir adalah perwujudan yang cangkupannya dari pembentukan hingga jadi (Gustami, 2006:11-14). Penambahan proses di dalam metode penciptaan ini terdapat pada tahap perancangan yang melalui beberapa langkah, yaitu perancangan detail, perancangan anatomi, dan perancangan pose karya. 
Pada penerapannya, penciptaan ini dimulai dari penggalian masa lalu penulis untuk mencari permasalahan yang masih belum terselesaikan, yaitu intoleransi terhadap kondisi fisik. Permasalahan tersebut kemudian dilanjut dengan mengumpulkan dan membandingkan dengan kejadian-kejadian di masyarakat, termasuk mencari usaha-usaha perjuangan melawan intoleransi. Dari poin pencarian data mengenai usaha-usaha perlawanan tersebut kemudian dicarilah sesuatu yang berhubungan dengan kejadian tersebut, sehingga dipilihlan qilin sebagai objek penciptaan.

Selain mengeksplorasi tema penciptaan, dilakukan pula eksplorasi terhadap pendukung penciptaan. Dikarenakan bentuk qilin yang menyerupai hewan, maka dilakukanlah pencarian literatur hingga pengamatan langsung terhadap satwa. Eksplorasi ini dilakukan sebagai referensi sekaligus sebagai pembanding di dalam penciptaan ini.

Sebelum memasuki tahapan perancangan, dilakukan juga penelusuran mengenai bahan. Penelusuran ini dilakukan untuk memilih teknik pengerjaan yang paling sesuai dan memperkirakan daya tahan bahan (termasuk susut muai) dari badan tanah liat. Penelusuran ini tidak dilakukan secara khusus dikarenakan eksplorasi mengenai bahan telah dilakukan oleh seorang kriyawan sejak pertama-kali ia mengenali bahan tersebut.

Sebagai hasil penelusuran bahan,, diputuskan bahwa penciptaan ini akan menggunakan teknik dasar pijit (pinch). Teknik ini dipilih karena bentuk qilin yang memiliki detail yang rumit. Selain itu, jumlah karya yang tidak banyak menjadikan teknik cetak untuk bentuk secara global tidaklah efektif. Namun, untuk bagian detail sisik, teknik cetak (khususnya cetak tekan) dapat digunakan untuk mempersingkat waktu dan menghemat tenaga pada proses pembentukan, terutama dikarenakan detail sisik yang bersifat repetitif.

Setelah pemilihan objek dan pemilihan teknik penciptaan, langkah pertama yang kemudian dilakukan adalah perancangan detail. Dikarenakan terdapat banyak sekali variasi bentuk qilin, baik secara visual maupun tekstual (Coleman, 2007:211,1061), maka di dalam perancangan anatomi dan perancangan detail pada penciptaan ini digunakanlah pendekatan teori adaptasi. Di dalam teori adaptasi disebutkan bahwa dalam penciptaan kembali karya dengan data yang sudah tidak jelas maka penciptaan tersebut dapat diimprovisasi dengan pengetahuan yang dimiliki penciptanya (Hutcheon, 2006:6-7).

Dikarenakan bentuk qilin yang chimeric atau memiliki deskripsi berupa perpaduan bentuk beberapa jenis hewan, maka digunakanlah teori anatomi komparatif sebagai landasan perancangan. Inti dari teori ini adalah bahwa hewan vertebrata memiliki susunan tulang yang serupa (Kardong, 2012:1-14). Oleh karenanya, perancangan detail pada penciptaan ini menggunakan sampel dari detail-detail berbagai jenis satwa yang kemudian dikembangkan sesuai dengan deskripsi bentuk qilin. Selain deskripsi, detail- detail tersebut juga dipadukan ataupun dibandingkan dengan karya-karya yang sudah ada.

Setelah rancangan detail yang telah dibuat kemudian berlanjut ke perancangan anatomi yang dilakukan dengan menggabungkan rancanganrancangan detail yang dibuat sebelumnya. Selain menggabungkan rancangan-rancangan detail yang telah dibuat, proses ini juga merancang bentuk tubuh yang detailnya tidak dibuat secara khusus dan merevisi detail-detail yang telah dibuat apabila terdapat bentuk yang kurang sesuai.

Setelah rancangan anatomi jadi, rancangan tersebut kemudian dikembangkan menjadi beberapa sketsa qilin dengan variasi pose yang berbeda-beda. Pose yang diterapkan pada rancangan-rancangan pose ini juga didapatkan pada saat eksplorasi bentuk satwa yang dilakukan bersamaan dengan pada saat eksplorasi deskripsi bentuk qilin. Sebelum digunakan sebagai referensi pada perancangan pose qilin, pose-pose tersebut dikaji dengan teori anatomi untuk memastikan bagaimana posisi tubuh hewan tersebut yang sesungguhnya.

Setelah rancangan pose dibuat, diseleksi, dan dipilih, proses penciptaan ini mengalami transisi ke tahapan selanjutnya, yaitu perwujudan. Sebelum tahapan ini dimulai, perlu dipersiapkan bahan dan alat, seperti mempersiapkan bahan baku tanah liat dan mempersiapkan alat-alat bantu, termasuk pembuatan cetakan detail sisik dan rambut. Selain bahan dan alat kerja, dipersiapkan pula model miniatur karya yang akan dibuat, atau yang terkadang disebut juga prototipe karya. Hal ini sangatlah penting untuk dilakukan karena untuk penciptaan keramik dengan teknik pijit yang pembentukannya dilakukan secara perlahan, apabila hal ini tidak dilakukan, jejak visual bentuknya dapat hilang di tengah prosesnya. Setelah keseluruhannya siap, mulailah pembentukan global, dari kaki, badan, hingga kepala. Setelah pembentukan ini selesai dan permukaannya dirapikan, dimulailah proses pencetakan dan pemasangan detail-detail sisik dan rambut. Setelah semua terpasang, dibuatlah detaildetail yang tidak dicetak, seperti telinga, tanduk, ekor, dan lain sebagainya. Setelah keseluruhan proses pembentukan selesai, karya kemudian didiamkan supaya mengering. Hal ini dilakukan minimal selama lima hari.

Pada saat karya-karya ini sudah selesai dibentuk dan sudah kering, karya-karya ini kemudian dibakar menggunakan tungku keramik. Proses ini menghabiskan waktu 6 hingga 10 jam untuk pembakaran dan sekitar 10 hingga 12 jam untuk pendinginan. Proses pembakaran ini dilakukan hingga mencapai suhu sekitar $1200^{\circ} \mathrm{c}$. Suhu ini dipilih karena dianggap cukup untuk pembakaran tanah liat berjenis suhu menengah atau stoneware (Ponimin, 2010:164). Proses pembakaran dan pendinginan ini harus dilakukan secara perlahan untuk menghindari resiko retak atau pecah pada badan keramik yang dapat diakibatkan oleh perubahan suhu yang drastis. 
Akhir dari penciptaan ini kemudian dilakukan dengan melakukan evaluasi. Evaluasi tersebut dilakukan dengan membandingkan keseluruhan hasil karya yang tercapai dengan tujuan awal penciptaan ini. Evaluasi ini juga mencari permasalahan-permasalahan yang luput dari pemikiran pada awal penciptaan untuk dijadikan saran dan kritik pada hasil karya ini. Hasil evaluasi ini kemudian disusun ke dalam bentuk laporan penciptaan.

\section{HASIL DAN PEMBAHASAN}

Secara keseluruhan, karya-karya yang dibuat ini mengambil bentuk dari salah satu deskripsi bentuk dari qilin, yaitu perpaduan rubah dan rusa bertanduk satu (Coleman, 2007:211). Meskipun begitu, pengaruh nama terjemahannya, dragon-horse, juga diberikan.

Fokus utama pada perancangannya qilin terdapat pada jumlah dan bentuk tanduknya, terutama dikarenakan jumlahnya yang tidak jarang dibuat lebih dari satu. Bentuk-bentuk dengan tanduk lebih dari satu tersebut biasanya muncul pada karya-karya qilin yang dibuat dengan kepala menyerupai chinese-dragon atau long. Awal proses Pada titik ini, muncul pertanyaan, bagaimana caranya membuat qilin bertanduk satu, tetapi juga memiliki bentuk menyerupai qilin bertanduk lebih? Pertanyaan tersebut dijawab dengan rancangan tanduk tunggal yang muncul dari tengah kepala, namun dibuat bercabang ke samping seperti tanduk rusa Dengan adanya cabang tersebut, tanduk tersebut terlihat seakan-akan berjumlah jamak, meskipun memiliki pangkal tunggal.

Sebagai kenyataan di dalam proses penciptaan, tidak semua ide muncul pada awal proses perancangan. Hal tersebut juga terjadi pada perancangan detail tanduk yang bercabang ke samping ini yang muncul pada saat pengembangan sketsa pose. Pada awalnya, rancangan tanduk dibuat bercabang secara vertikal saja. Ide untuk mengembangkan dimensi tanduk tersebut muncul dari pengamatan pada pose-pose rusa (sebagai referensi perancangan pose) yang menjadikan tanduk tunggal yang bercabang secara vertikal terasa seperti gimmick atau cabang yang semu.

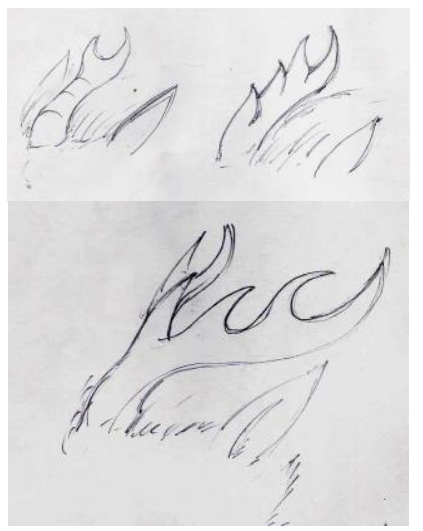

Gambar 1. Proses pancangan tanduk
Dikarenakan penggunaan teori anatomi komparatif sebagai landasan perancangan bentuk qilin, perancangan detail bagian-bagian tubuh lainnya hanya menggunakan referensi bentuk-bentuk bagian tubuh dari jenis-jenis hewan yang disebutkan pada deskripsi bentuk qilin. Dimulai dari kaki yang bertapal yang disebut menyerupai kuda ataupun rusa. Terdapat beberapa variasi bentuk kaki yang dibuat. Selain kaki yang serupa kaki kuda ataupun rusa, dibuat pula rancangan kaki dengan dasar kaki rubah yang diberi tapal di ujungnya. Kemudian untuk bagian kepala hingga badan, sampel yang digunakan adalah dasar kerangka rubah. Meskipun hewan ini susah untuk ditemukan, bentuk rubah tetap digunakan karena kemiripan bentuk kerangkanya dengan kerangka anjing, sehingga anjing pun dapat dijadikan pembanding terhadap data-data mengenai bentuk anatomis rubah. Bentuk tubuh tersebut kemudian digabungkan dengan kaki yang dipilih sebelumnya.
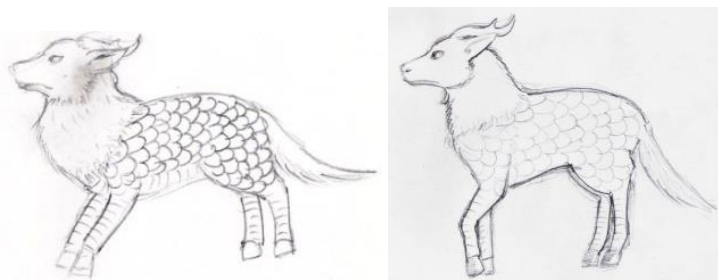

Gambar 2. Beberapa variasi rancangan anatomi

Detail pelengkap pada karya-karya yang diciptakan ini, seperti sisik dan rambut, mengambil referensi dari karya-karya qilin tradisional. Referensi tersebut kemudian dikembangkan sehingga muncul kesan cembung dengan pangkal sisik lebih masuk ke dalam.

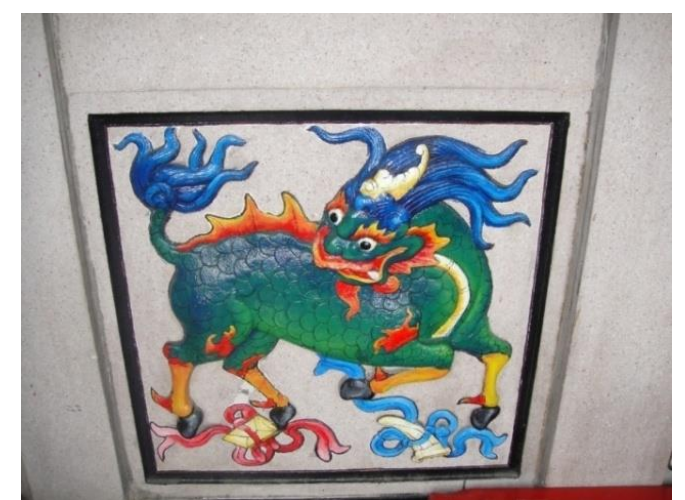

Gambar 3. Relief qilin tradisional di Klenteng Fuk Ling Miau

Setelah potongan-potongan detail disusun menjadi rancangan anatomi, proses berlanjut ke proses perancangan pose. Perancangan pose dilakukan dengan mengembangkan referensi-referensi visual mengenai perilaku satwa yang telah didapatkan di tahap eksplorasi. Setelah mengidentifikasi bagian-bagian tubuhnya, bagian-bagian tubuh hewan tersebut kemudian digambar dengan bagian-bagian tubuh yang berbeda, sesuai dengan deskripsi detail qilin. Proses ini 
dilakukan untuk mengetahui kesesuaian pose hewan tersebut dengan anatomi qilin. Hewan-hewan yang dijadikan referensi pose adalah: kuda, rusa (dan sebangsanya), dan rubah (dan sebangsanya, termasuk di antaranya anjing dan serigala). Proses perancangan ini kemudian berkembang menjadi beberapa rancangan karya, beberapa berupa rancangan karya dua dimensi, sisanya berupa rancangan karya tiga dimensi.

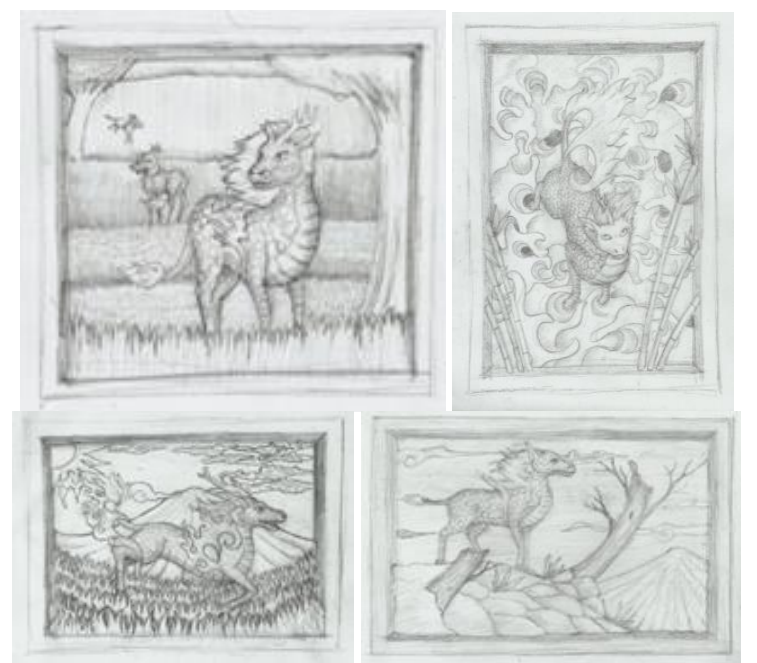

Gambar 4. Rancangan karya dua dimensi

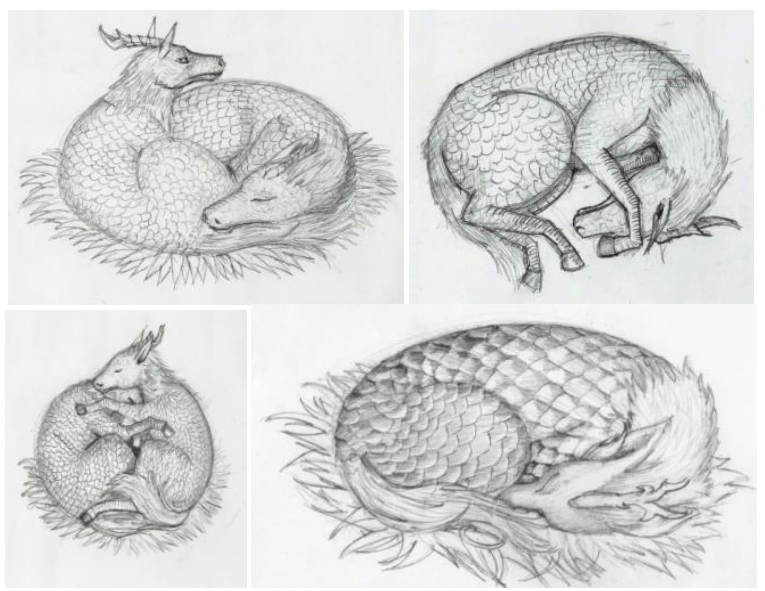

Gambar 5. Rancangan karya tiga dimensi

Referensi pose yang digunakan untuk perancangan pose adalah pose-pose hewan yang sedang tidak berada di dalam ancaman pemangsa. Dengan kata lain, hewan-hewan tersebut sedang terbebas dari segala bentuk halangan. Pose-pose ini diambil ini sebagai perwakilan bentuk kebebasan yang dialami masyarakat etnis Tionghoa pasca dicabutnya Inpres No.14/1967.

Di antara sketsa-sketsa rancangan yang telah dibuat, sketsa-sketsa rancangan yang kemudian dipilih untuk diwujudkan adalah dua sketsa karya qilin tiga dimensi yang sedang dalam posisi tidur. Pose ini dipilih karena hewan biasanya tidur di tempat-tempat yang aman, terbebas dari ancaman (pemangsa).

Setelah sketsa dipilih, tahapan beralih ke tahapan perwujudan. Secara keseluruhan karya-karya yang dibuat berupa karya-karya terakota atau keramik tanpa glasir. Tidak diberinya glasir bertujuan untuk menjaga detail pada permukaan badan tanah. Hal tersebut dikarenakan sifat glasir yang melapisi permukaan luar sehingga glasir sering-kali berujung menutupi atau menghilangkan detail-detail kecil. Dikarenakan tubuh qilin yang permukaannya dipenuhi oleh rambut dan sisik maka diputuskan bahwa permukaan badan karya tidak diberi glasir.

Seluruh proses penciptaan yang telah dilalui ini berhasil menghasilkan dua karya patung terakota yang berwujud qilin. Pada karya pertama, digambarkan terdapat seekor qilin yang tidur sendirian di atas rerumputan. Rerumputan di karya ini digunakan sebagai perwakilan padang rumput (savanna). Sebagai lingkungan yang terbuka, padang rumput juga merupakan wilayah yang rawan dari serangan pemangsa. Oleh karenanya, tidur di tengah-tengah wilayah seperti ini menandakan tiadanya ancaman di wilayah tersebut. Sama halnya dengan hal tersebut, qilin pada karya ini digambarkan tidur di atas rerumputan dikarenakan tiadanya ancaman dari "predator". Maksudnya adalah, qilin yang merupakan kebudayaan Tionghoa dan dahulunya mendapatkan pelarangan dari Inpres No.14/1967, kini telah terbebas dari ancaman tersebut.

Tidak jauh dari karya pertama, makna pada karya kedua juga memiliki banyak pemaknaan yang sama. Kesamaan tersebut terdapat pada pose tidur dan berada diatas rerumputan. Perbedaannya kemudian adalah jumlah qilin dan posisi tidurnya. Apabila pada karya pertama lebih mengarah ke kebebasan dalam mengekspresikan diri, makna pada karya kedua ini lebih mengarah pada kebebasan dalam mengekspresikan kebudayaan warisan nenek moyangnya.

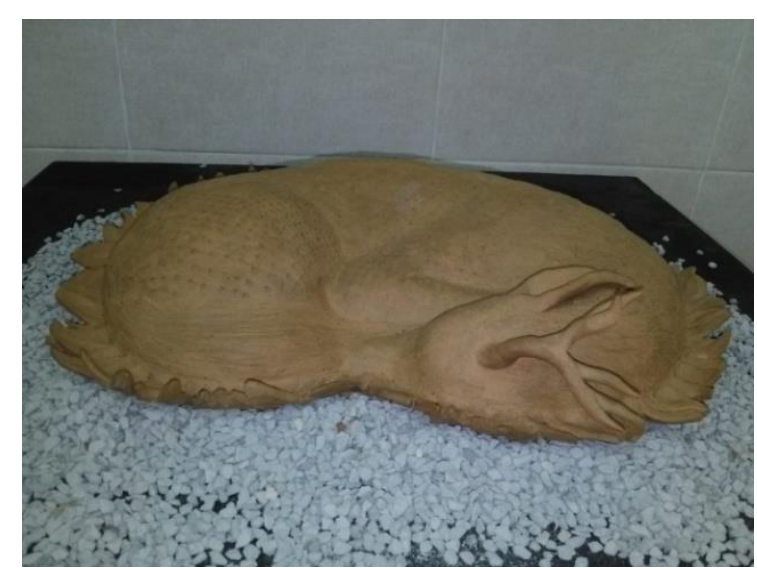

Gambar 6. Karya 1

Judul: Ketenteraman

Ukuran: 35x29x10 (hanya untuk ukuran badan keramik)

Bahan: Stoneware Sukabumi

Teknik: Pijit, Cap, Gores, Dibakar hingga $1200^{\circ} \mathrm{c}$ 


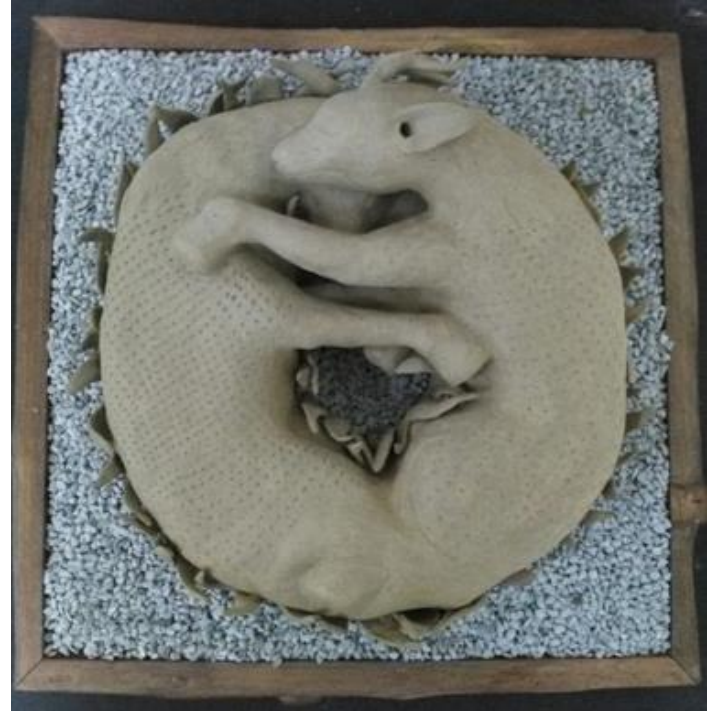

Gambar 7. Karya 2

Judul: Kedamaian

Ukuran: 35x35x14 (hanya untuk ukuran badan keramik)

Bahan: Stoneware Sukabumi

Teknik: Pijit, Cap, Gores, Dibakar Hingga $1200^{\circ} \mathrm{c}$

\section{PENUTUP}

Sebagai karya yang menggunakan tema dari kebudayaan yang berbeda dengan penciptanya, terdapat banyak hal yang harus dipelajari di awal proses penciptaan tersebut. Tidak hanya hal-hal yang terlihat saja, namun nilai-nilai yang terkandung pun harus ikut dipelajari. Alhasil, seluruh proses eksplorasi tersebut selain memberikan ide mengenai bentuk karya yang akan diciptakan, juga memberikan gambaran mengenai pola pikir masyarakat dengan kebudayaan tersebut. Hal tersebut menjadikan penciptaan karya dengan menggunakan tema kebudayaan-kebudayaan lain sebagai media yang dapat dianggap baik untuk mempelajari kebudayaan lainnya.

Wujud qilin yang diambil sebagai representasi kebudayaan Tionghoa memiliki banyak variasi akibat asalnya yang berasal dari kebudayaannya yang sudah ada di dunia selama ribuan tahun. Hal tersebut memberikan kebebasan dalam menginterpretasi dan merancang bentuknya. Sebagai hasil karya yang mengacu pada deskripsi bentuk qilin yang dipadukan dengan pengetahuan modern mengenai alam, karyakarya yang tercipta ini pada satu sisi memang menjawab ketidak-puasan atas keberagaman deskripsi dan bentuk yang saling bertentangan yang ditemui pada saat eksplorasi. Pada sisi yang lain, hal yang dilakukan ini juga mengurangi kesan kebudayaannya akibat pengurangan penggayaan bentuk pada kepalanya. Dikarenakan hal ini, meskipun cara seperti ini baik untuk memvisualkan konsep bentuk pada qilin dari perspektif pengetahuan modern, namun hal ini menjadikan karya tidak sepenuhnya sukses karena menimbulkan ketidak-puasan pada penikmat seni yang justru mencari dan rasa-rasa tradisional tersebut.
Berbeda dengan penggunaan anatomi hewan pada perancangan karya yang memiliki kelemahan tersebut, penggunaan perilaku hewan untuk menarasikan kondisi atau ekspresi sang qilin juga dinilai cukup efektif dalam penggunaannya. Hal tersebut dikarenakan qilin yang merupakan hewan mitologi. Dengan kata lain, apabila diberi ekspresi berdasarkan ekspresi manusia, maknanya justru akan menjadi ambigu. Sebagai contoh, apabila dibuat dengan wujud qilin yang berlari seperti kuda, meskipun dengan ekspresi manusia itu merupakan tanda kebebasan karena dianggap dapat lari ke mana saja, namun hewan pada umumnya lari untuk menghindar dari ancaman. Hal tersebut menjadikan karya-karya ini apabila dibentuk demikian, maknanya justru akan berubah menjadi ambigu antara si qilin yang merupakan representasi kebudayaan Tionghoa ini sedang menikmati kebebasannya atau sosok qilin tersebut sedang melarikan diri dari pemangsa yang bernama Inpres No.14/1967? Oleh karenanya, pose tidur nyenyak menjadi lebih efektif karena lebih memberikan kesan tenang, terbebas dari ancaman apapun.

\section{DAFTAR PUSTAKA}

Coleman, J.A..(2007), The Dictionary of Mythology, an A-Z of Themes, Legends, and Heroes, Arcturus, London.

Eriyanti, Fitri. (2006) "Dinamika Posisi Identitas Etnis Tionghoa dalam Tinjauan Teori Identitas Sosial" dalam Jurnal Demokrasi, Vol V No 1, Universitas Negeri Padang.

Fittrya, Laylatul. (Mei 2013), "Tionghoa dalam Diskriminasi Orde Baru Tahun 1967-2000" dalam Avatara, e-Journal Pendidikan Sejarah, Vol.1 No 2, Universitas Negeri Surabaya.

Gustami, SP..(Desember 2006), “'Trilogi Keseimbangan Ide' Dasar Penciptaan Seni Kriya: Untaian Metodologis" dalam Dewa Ruci, Jurnal Pengkajian \& Penciptaan Seni, BP ISI Surakarta, Surakarta.

Hutcheon, Linda. (2006), A Theory of Adaptation, Routledge, New York.

Kardong, Kenneth. (2012), Vertebrates: Comparative Anatomy, Function, Evolution, Sixth Edition, Mc-Graw Hill, New York.

Ponimin. (2010), Desain dan Teknik Berkarya Kriya Keramik, Lubuk Agung, Bandung.

Sari, Intan Permata. (Desember 2017), "Harmoni dalam Kebhinekaan (Kearifan Lokal Masyarakat Pulau Enggano Provinsi Bengkulu dalam Mengatasi Konflik)" dalam Jurnal Antropologi: Isu-Isu Sosial Budaya, Vol. 19 No. 2, Universitas Andalas, Sumatra Barat 
Setiawan, Eko. (Juli 2017), “Konsep Teologi Pluralisme Gus Dur dalam Meretas Keberagaman di Indonesia" dalam Asketik, Vol. 1 no. 1, IAIN Kediri.

Huda, Samsul. (2010), “Ulasan Buku: Orang Indonesia Tionghoa dan Persoalan Identitas" dalam Kontekstualita: Jurnal Penelitian Sosial Keagamaan, Vol. 25 No. 1, UIN Jambi.

Kusuma, Rafles Abdi. (Desember 2019), "Dampak Perkembangan Teknologi Informasi dan Komunikasi terhadap Perilaku Intleransi dan Antisosial di Indonesia" dalam Mawa'izh: Jurnal Dakwah dan Pengembangan Sosial Kemanusiaan, Vol 10 no. 2, IAIN Bangka Belitung.

CNN Indonesia. (5 Agustus 2019), Sempat Batal karena Difabel, Dokter Gigi Romi Jadi CPNS, https://www.cnnindonesia.com/nasional/ 20190805174001-20-418578/sempat-bata l-karena-difabel-dokter-gigi-romi-jadi-cpns

Pertana, Pradito Rida. (2 April 2019), Perbedaan Agama Membuat Slamet Ditolak Tinggal di Dusun Karet Bantul, https://news.detik.co m/berita-jawa-tengah/d-4494241/perbed aan-agama-membuat-slamet-ditolak-tingg al-di-dusun-karet-bantul

Purbasari, Verbena Ayuningsih \& Suharno. (Juni 2019), "Interaksi Sosial Etnis Cina-Jawa Kota Surakarta" dalam Jurnal Antropologi: Isu-Isu Sosial Budaya, Vol. 20 No. 1, Universitas Andalas, Sumatra Barat

Sari, Elia Nurindah \& Samsuri. (Juni 2020), "Etnosentrisme dan Sikap Intoleran Pendatang terhadap Orang Papua" dalam dalam Jurnal Antropologi: Isu-Isu Sosial Budaya, Vol. 22 No. 1 Universitas Andalas, Sumatra Barat

Wicaksono, Indra. (November 2018) "Membumikan Pancasila Arti Penting Menegakkan HAM sebagai Tameng Toleransi Keberagaman" dalam Lex Sientia Law Review, Vol. 2 No. 2, Universitas Negeri Semarang, Semarang 